\title{
Small Holder Camel Milk Production Performance in Jigjiga District, Somali Regional State, Eastern Ethiopia
}

\section{Abdulahi Mahamed, Abdifatah Haji, Kibru Beriso and kefyalew Gebeyew*}

Jijiga University, Collage of Dry Land Agriculture, Department of Animal and Range Science, PO Box 1020, Jijiga, Ethiopia

*Corresponding author: Jijiga University, Collage of Dry Land Agriculture, Department of Animal and Range Science, PO Box 1020, Jijiga, Ethiopia, Tel: +251-931-906-414; E-mail: kefyalewgebeyew@yahoo.com

Rec date: Jun 13, 2015; Acc date: Oct 13, 2015; Pub date: Oct 15, 2015

Copyright: (c) 2015 Mahamed A, et al. This is an open-access article distributed under the terms of the Creative Commons Attribution License, which permits unrestricted use, distribution, and reproduction in any medium, provided the original author and source are credited.

\begin{abstract}
This study was conducted in Jigjiga District of Fafan zone with the objectives to assessed small holder Camel milk production performance. Four kebeles were selected randomly from total of 33 kebeles of the District. Sample households were selected purposively based on the presence of lactating camel in the household. Accordingly ten (10) household were selected from each kebele. Therefore the total sample size was 40 respondents. Out of this $80 \%$ and $20 \%$ were male and female, respectively. The data were collected from primary source by using semistructured questionnaires. The age of the respondents were $20-30(55 \%), 10-20(20 \%$,) and $30-40(25 \%)$. Majority $(60 \%)$ of the respondents were illiterate, whereas only $40 \%$ of them were literate. Milking yield of the area was from 1-6 liter per animal per day. According to respondent's response, Majority (75\%) of them produced 3 liters per each lactating camel produces, where $15 \%$ of them can produce equal or more than four (4) litres per day, where only $10 \%$ of them produced two liter per day. Almost all $(90 \%)$ of the respondents camel produce high milk yield during the spring season, where $(10 \%)$ of the them can bring with a good output of milk production during autumn season. majority $(55 \%)$ of the respondents replied that camel's milk production can persist with a time of $(24)$ hrs, where $30 \%$ of the respondents camel's milk can exist (36) hrs, Where only15\% of the respondents camels' milk can exist (48) hrs. the main factors that affect camel milk were feed (45\%), drought (20\%), and disease (35\%). The weaning age of camel in the study area ranges from 6-18 months, 18 months (70\%) is the most common one. The milking frequencies were ranges from 2-3 times per day. Whereas, 3 times per day $(80 \%)$ are common. Majority of the respondents utilize traditional milk handling equipment's (65\%) Dhiil (hourglass) and (35\%) Gaawe. In conclusion, Due to lack of better management, nutrition and health care camel milk production is low. Therefore, Successful mitigation measures for improved and sustained camel milk production requires contribution and clear roles of a number of stakeholders.
\end{abstract}

Keywords: Milk; Camel; Yield; Drought; Feed

\section{Introduction}

Pastoral production systems are those "in which at least 50 percent of the gross incomes of households (i.e., the value of market production and the estimated value of subsistence production consumed by households) come from pastoralism or its related activities, or else, where more than 15 percent of households' food energy consumption involves the milk or dairy products they produce" [1]. With few exceptions, camels are associated with nomadic or seminomadic production systems. However, these systems are undergoing rapid adaptive changes and transformations to cope with emerging demographic and economic factors [2]. Camels have the ability to survive under harsh climatic conditions and have the potential to enhance pastoral household livelihoods under this distressful environment [3]. The species of domestic camels found in Ethiopia is one-humped dromedary camel (Camelus dromedarius). Camels play diverse roles in livelihood of the poor pastoralists, including the building of assets, insurance against unexpected events; have spiritual and social values, traction and movement of goods, food supply income generation in Ethiopian pastoralists and very recently it plays pronounced role in the export revenue of the country in both live animal and carcass export $[4,5]$.
Camels have an outstanding milk production in harsh environmental conditions in which they are kept. The camels produce more milk when compared with cattle and small stocks under the same harsh environmental conditions and its lactation persists well into the dry seasons and rarely ceases even during extended dry spells. Camel's milk is preferred to milk of other livestock species because of its taste, nutritious value, health reasons and it is perceived that camel milk prevents thirst even when walking for a long distances. Depending on the accessibility of the market, surplus camel milk is also sold for cash income by members of the communities [6].

Despite the camel milk considerable contribution to food security in semi dry and dry zones and its being a major component of the agropastoral systems in vast pastoral areas in Ethiopia Somali regional state. Information on camel milk production and handling systems especially in Ethiopia Somali regional state is very limited. Therefore; the aim of this study was to assess small holder Camel milk production performance in Jigjiga District, Eastern Ethiopia.

\section{Statement problem}

Camel milk can certainly play a far more important role in the prevention of malnutrition than it does today. Growing and raising foodstuffs for the rapidly increasing human population is especially precarious in the hot and arid zones of the world-the very areas where the camel is one of the few animals not only to survive, but also to 
Page 2 of 4

benefit man. Similarly, Jigjiga is one of District of the Somali Region, Ethiopia which belong high percent of camel herding that support their livelihood. However, there is no more information which is done on the camel milk production performance in the study.

\section{Significant of the study}

These studies are very important to camel producers in Jigjiga District. It will help other researchers as a source of information and also will help government policy makers to undertake different projects that can enhance the sustainability of camel production. Moreover, this study will help both national and international organizations to know more about camel milk production in the study area.

\section{Methodology}

\section{Descriptions of stud area}

The Study was conducted in jigjig District, which is the capital city of Somali Regional State (SRS) in eastern Ethiopia and is one the District in the fafan zone. The population in the Zone is mainly from Somali tribes which are Muslims and agro pastoralists. Household size averages 6 and 5.3 heads in rural and urban areas, respectively. The zonal household size averages to 5.9, which is less than the average of 6.7 for the Somali Region [7]. It far apart $625 \mathrm{~km}$ east of capital city of Ethiopia Addis Ababa, and $65 \mathrm{~km}$ west of Wachale border with Somali land. It has latitude and longitude $9^{\circ} 25 \mathrm{~N}, 42^{\circ} 6 \mathrm{E}$ with latitude ranges from $1600-1700 \mathrm{~m}$ above sea level and reserve annual rain fall that takes from $500-600 \mathrm{~mm}$. The main monthly minimum temperature take to measure $5.8^{\circ} \mathrm{C}$ in number to $14^{\circ} \mathrm{C}$ in July to September and maximum monthly temperature rise from $25^{\circ} \mathrm{C}, 29^{\circ} \mathrm{C}$ July-march.

\section{Sampling techniques}

Initially discussions were held with district livestock experts; secondary data were collected; published and unpublished information were assessed. Based on the information gained, four kebeles were selected randomly from total of 33 kebeles of the District. Sample households were selected purposively based on the presence of lactating camel in the household. Accordingly ten household were selected from each kebele. Therefore, the total sample size was 40 .

\section{Methods of data collection}

The Data were collected from primary source by using semistructure questionnaires and interview. The data that were collected includes:- Educational background, age distribution, perceptions of pastoralists and agro-pastoralist about the camel milk yield, main problems in the study area and general information about the house hold and family size.

\section{Data analysis}

The data collected by using semi-structured questionnaire were entered in to MS-excel and imported to SPSS (version 16) software and also coded for analysis. Descriptive statistics were used to describe quantitative factors. Standard error of mean \pm (SE) is used to describe means while percentage is used for describing qualitative characteristics. The data was analyzed one way analysis of variance (one-ANOVA). The results were expressed in frequency, and percentage of the results from the questionnaire.

\section{Result and Discussion}

\section{Gender, age and educational status of respondents}

The number of male respondents were (80\%), where only (20\%) of them were female. The ages of respondents in the study are (Table 1). The age of the sample respondents were categorized into three parts; the age interval 20-30 (55\%) were the highest portion gathered from this information, where the age interval 10-20 (20\%), and 30-40 were $(25 \%)$. Majority $(60 \%)$ of the respondents were illiterate, where only $40 \%$ of them were literate. This also facilitated that camel milk yield and milk persistent data collection in a simplified form to analyse and interpret the result due to the sufficient information we gained (Table 2).

\begin{tabular}{|l|l|l|l|}
\hline Variable & Category & Frequency & Percentage (\%) \\
\hline \multirow{3}{*}{ Gender } & Male & 32 & $80 \%$ \\
\cline { 2 - 4 } & Female & 8 & $20 \%$ \\
\hline \multirow{3}{*}{ Age of respondents } & $10-20$ & 8 & $20 \%$ \\
\cline { 2 - 4 } & $21-30$ & 22 & $55 \%$ \\
\cline { 2 - 4 } & $31-40$ & 10 & $25 \%$ \\
\cline { 2 - 4 } & $>40$ & 0 & $0 \%$ \\
\hline \multirow{2}{*}{ Educational level } & Illiterate & 24 & $60 \%$ \\
\cline { 2 - 4 } & Literate & 15 & $40 \%$ \\
\hline
\end{tabular}

Table 1: Gender, Age and education level of Respondents.

\begin{tabular}{|l|l|l|}
\hline Camel Milk yield Per day & Frequency & Percentage \\
\hline 2 liter & 4 & $10 \%$ \\
\hline 3 liter & 30 & $75 \%$ \\
\hline$\geq 4$ liter & 6 & $15 \%$ \\
\hline
\end{tabular}

Table 2: Camel milk yields.

\section{Camel milk yield performance}

Daily milk yield of camels in the study areas range from 1.0-6.0 liters per day depend on feed availability, season and water access which is below the result of Simenew et al. [8]. Mean daily milk yield of 2-6 liters was reported by FAO [9] in Somalia and according to Farah et al [10] milk production of Somali camels was 5-6 kg. Kebebew recorded milk yield of $7.5 \mathrm{~kg}$ per day in the Ogaden camel keeping area in east Ethiopia [11]. Daily milk yield of $3-10 \mathrm{~kg}$ was reported in eastern Ethiopia by Bekele and Kebebew [12]; while Abebe [13] registered daily yield of 8-10 kg in Ogaden camels in eastern Ethiopia.

The variations could be due to the number of animals involved in the study, difference in pastoral practice such as milking frequency and suckling to breed difference as well as other management or environmental difference. According to the respondents majority $(75 \%)$ of the respondents produced milk three $(3 \mathrm{~L})$ litres per each camel produces at one milking time, where $15 \%$ of them responded that a camel can produce equal or more than four (4) litres per day, where only $10 \%$ of the respondents said that it is produced by two litres per day. The estimated daily milk yield during the early stage of 
Page 3 of 4

lactation in this study was similar to that reported by Mehari et al. [14] and Abebe [13] while the estimated daily milk yield during middle and end of lactation were lower than that reported by Mehari et al. [14]. FAO milking practice is also known to affect daily milk yield. Allowing the calf to suckle for a few minutes before hand milking makes it difficult to measure actual milk yield while milking without any previous mechanical stimulation of the mammary gland, leads to lower yields [9].

\section{Optimum milk yield season}

As Table 3 indicated below, most of the respondents (90\%) said that during spring season is camel produce high output of milk. This may be the time where ample feed and water resource available time of the year. Whereas, small portion (10\%) of the respondents' respond that autumn can bring with a good output of milk production. This confirms that camel milk yield is very high in the spring season, where the other seasons have less milk output. Higher mean daily milk off take was reported during the rainy season in the Errer valley [15] and in Babilie and Kebribeyah woredas of Jijiga zone [16]. Farah et al. [10] has also reported higher milk yield during the rainy season in Somalia. Highest daily milk off take coincides with the rainy season when there is an abundance of many types of vegetation.

\begin{tabular}{|l|l|l|}
\hline Season of milk Production & Frequency & Percentage \\
\hline Spring & 36 & $90 \%$ \\
\hline Autumn & 4 & $10 \%$ \\
\hline
\end{tabular}

Table 3: Season of optimum camel milk production.

\section{Camel's milk shelf life}

As shown in Table 4 below, majority (55\%) of the respondents replied that camel's milk production can persist with a time of (24) hrs, where $30 \%$ of the respondents said that camels' milk can exist (36) hrs, Where only $15 \%$ of the respondents said that camels' milk can exist (48) hours. The shelf life of camel milk 24 -48 hrs.

\begin{tabular}{|l|l|l|}
\hline Camel Milk Shelf life & Frequency & Percentage \\
\hline $24 \mathrm{hrs}$ & 22 & $55 \%$ \\
\hline $36 \mathrm{hrs}$ & 12 & $30 \%$ \\
\hline $48 \mathrm{hrs}$ & 6 & $15 \%$ \\
\hline
\end{tabular}

Table 4: Camel's Milk shelf life.

\section{Weaning age}

Weaning is at $8-18$ months, depending on the browse situation, the milk production of the female, and the growth of the calf. In traditional pastoral systems, the camel calf is weaned at any time between 3 and 18 months, with an average of 12 months, Mukasa-Mugerwa [17]. Young camels can be weaned within a given period interval in order to make them strong. As can be seen the show below Table 5, majority (70\%) of the respondents responded that 18 months can be weaned for young camels, where $20 \%$ of the respondents said that 12 months must be weaned for young camels; this ratifies that young camel can be weaned with eighteen months in order to sustain young camel reliability. The current findings above Mayouf et al. [18].

\begin{tabular}{|l|l|l|}
\hline Weaning age & Frequency & Percentage \\
\hline 6 months & 4 & $10 \%$ \\
\hline 12 months & 8 & $20 \%$ \\
\hline 18 months & 28 & $70 \%$ \\
\hline
\end{tabular}

Table 5: Weaning Age for Young Camels.

\section{Major factors affecting camel milk production}

The main factors that affect camel milk are feed, drought, and disease (Table 6), which is in line with Simenew et al. [8]. Majority (45\%) of the respondents said that camel milk production is quietly affected by the feed they consume, where $20 \%$ of the respondents said that drought has an effect on the production of milk where only $35 \%$ of the respondents said that disease has an effect on the production of milk. This confirms that the most factors affecting of milking production were feed.

\begin{tabular}{|l|l|l|}
\hline Factors affect for milk & Frequency & Percentage \\
\hline Feed & 18 & $45 \%$ \\
\hline Drought & 8 & $20 \%$ \\
\hline Disease & 14 & $35 \%$ \\
\hline
\end{tabular}

Table 6: Major factors that affect camel milk production.

\section{Camel milking frequency}

As indicates in Table 7 below, Majority (80\%) of the respondents milking time were 3 times and more, where only $20 \%$ of the respondents responded that 2 times or greater than can be used for milking time. This finding is in reasonable agreement with the finding of Ishag and Ahmed [19] and Mehari et al. [14]. This shows that most of the respondents emphasized that 3 times or more are possible to camel milking. Milking frequency is also indicated as the other factor which influences daily milk yield as increasing milking frequency from two to four increased milk yield from 1 to 1.5 liters/day $[9,16]$.

\begin{tabular}{|l|l|l|}
\hline Milking frequency & Frequency & Percentage \\
\hline 2 times & 8 & $20 \%$ \\
\hline 3 times & 32 & $80 \%$ \\
\hline
\end{tabular}

Table 7: Camel milking frequencies.

\section{Milk handling equipment's}

Majority (65\%) of the respondents replied that milk equipment of Somali gaawe is used for handling of camel milking, where only $35 \%$ of the respondents said that dhiil (hourglass) the equipment used for milking and storage. This shows that the most milk equipment used were Gaawe (Table 8).

\section{Conclusions}

The production of the Ethiopia somali camels milk is not fully exploited as they are purely dependent on natural vegetation. Due to lack of better management, nutrition and health care camel milk 
Citation: Mahamed A, Haji A, Beriso K, Gebeyew K (2015) Small Holder Camel Milk Production Performance in Jigjiga District, Somali Regional State, Eastern Ethiopia. J Veterinar Sci Technol 6: 267. doi:10.4172/2157-7579.1000267

Page 4 of 4

production is low. Therefore, Successful mitigation measures for improved and sustained camel milk production requires contribution and clear roles of a number of stakeholders.

\begin{tabular}{|l|l|l|}
\hline Milk equipments & Frequency & Percentage \\
\hline Dhiil & 14 & $35 \%$ \\
\hline Gaawe & 26 & $65 \%$ \\
\hline
\end{tabular}

Table 8: Milking equipments.

\section{References}

1. Swift J (1998) Les Grand's Themes du Development Pastoral et le cas de Quelques Pays Africains. FAO/ESH Working Papers on Pastoral and Agro-pastoral Societies, Rome.

2. Hashi AM (1991) Pastoral resource use systems of Somalia. In: FAO Report-Sub regional Seminar on the dynamics of pastoral land and resource tenure in the horn of Africa. Mogadishu, FAO, Rome 8: 1-1.

3. Ahmed A, Azeze A, Babiker M, Tsegaye D (2002) Post Drought recovery strategies among the pastoral households in the horn of Africa: A review. Development Research Report Series no. 3. OSSREA, Addis Ababa, Ethiopia p: 80.

4. Ali A, Al-Sobayil F, Tharwat M, Al-Hawas A, Ahmed A (2004) Causes of infertility in female camels (Camelus dromedarius) in middle of Saudi Arabia. J Agric Vet Med 2: 59-69.

5. SOS-Sahel (2007) Pastoralism in Ethiopia: Its total economic values and development challenges. Project Evaluation Report: Oxfam Canada, Addis Ababa, Ethiopia pp: 1-33.

6. Kaufman BA, Binder C (2002) Production aims and functions of camels in Kenyan pastoral systems; in proceedings of collaborative research project on camel breed differentiation and pastoral camel breeding strategies within the KARI/EU Agriculture/livestock research support programme for Kenya.

7. JZOA (Jijiga Zone Agricultural Office) (2001) Jijiga Zone Agricultural Office Annual report: Jijiga.
8. Simenew K, Dejen T, Tesfaye S, Fekadu R, Tesfu K, et al. (2013) Characterization of Camel Production System in Afar Pastoralists, North East Ethiopia. Asian Journal of Agricultural Sciences 5: 16-24.

9. FAO (Food and Agricultural Organization) (2001) the technology of making cheese from camel milk (Camelus dromedarius). FAO Animal Production and Health Paper, Rome, Italy.

10. Farah KO, Nyariki DM, Ngugi RK, Noor IM, Guliye AY (2004). The Somali and the camel: Ecology, management and economics. Kamla-raj Anthropologist 6:45.

11. Kebebew T (1998) Milk production, persistency and composition of pastorally managed Ogaden camels in eastern Ethiopia, MSc Thesis Presented to the School of Graduated Studies of Haramaya University, Haramaya, Ethiopia Pp: 94.

12. Bekele T, Kebebew $\mathrm{T}$ (2001) Camel production and productivity in eastern lowlands of Ethiopia. In: Proceedings of the 9th Ethiopian Society of Animal Production (ESAP). August, Addis Ababa, Ethiopia pp: 145-164.

13. Abebe W (1991) Traditional husbandry practices and major health problems of camels in the Ogaden. Nomadic People, 29: 21-29.

14. Mehari Y, Mekuriaw Z, Gebru G (2007) Camel and camel product marketing in Babilie and kebribeyah woredas of the Jijiga Zone, Somali Region, Ethiopia. Livestock Research for Rural Development 19: 4.

15. Zeleke M (1998) Productivity, reproductive and health monitoring study on camel herd at Errer valley. MSc Thesis Presented to the School of Graduated Studies of Haramaya University, Haramaya, Ethiopi p. 98.

16. Yohannes M, Zeleke M, Getachew G (2007) Potentials of camel production in Babilie and Kebribeyah woredas of the Jijiga zone, Somali region, Ethiopia. Livestock Research for Rural Development 19:4.

17. Mukasa-Mugerwa E (1981) the camel (Camelus dromedarius): a bibliographical review. ILCA Monograph 5, Addis Ababa, Ethiopia: ILCA.

18. Mayouf R, Benaissa MH, Bentria Y, Aoune FZ, Halis Y (2014) Reproductive Performance Of Camelus Dromedarius In The El-Oued Region, Algeria. Online Journal of Animal and Feed Research 4: 102-106.

19. Ishag A, Ahmed M (2011) Characterization of production system of Sudanese camel breeds. Livest Res Rural Dev 23: 5-6. 